\title{
CAN LAW ON PROBATION IMPROVE THE IMPLEMENTATION OF THE MEASURES FOR PROVIDING THE DEFENDANT'S PRESENCE IN THE CRIMINAL TRIALS IN MACEDONIA?
}

\author{
Boban Misoski, PhD, Associate Professor \\ University "Ss. Cyril and Methodius", Faculty of Law "Iustinuianus Primus" \\ Goce Delcev 9B, Skopje, Republic of Macedonia \\ b.misoski@pf.ukim.edu.mk; bmisoski@yahoo.com
}

\begin{abstract}
The author critically elaborates the jurisdiction of the new Probation Service as regulated within the provisions of the newly enacted Law on Probation in Republic of Macedonia. He states that the Macedonian legislator has omitted to regulate one very important part of the Probation service's jurisdiction, such as the implementation of the measures for providing the defendant's presence during the criminal procedure. The author stresses the fact that in one broader European sense, the Probation Services has imminent jurisdiction regarding the proper implementation of these measures, as ordered by the courts. Through this jurisdiction the probation service is serving to the court as Pre-trial service. In order to overcome this situation, author initially examines the connection between these measures and the Probation service and in addition provides specific suggestions for further improvement of Law on Probation provisions.
\end{abstract}

Keywords: measures for providing defendant's presence, probation, house detention, electronic monitoring

\section{INTRODUCTION}

Measures for providing of the defendants' presence are often seen as necessary evil for effective and efficient commencement of the criminal trials. This is due to the fact that these measures are bearing significant restrictions to the defendants' basic human rights guaranteed during the criminal trials while the defendant is primarily observed as innocent until proven guilty beyond reasonable doubt. This means that trough the imposition of these measures during the criminal trial defendants' rights generally and in particular right to liberty and right to free movement are severely restricted despite the fact that the defendant is considered innocent. Henceforward, extensive implication of these measures could even harm defendants' presumption of innocence. Due to these reasons implication of the measures for providing defendant's presence during the criminal trials by the court should be restricted only in those cases where they are necessary of inevitable. For these 
reasons the courts should address extra caution while deciding which measure is most suitable to implement while at the same time to provide al less intrusion to the defendant's guaranteed rights.

For these reasons, while deciding which measure for providing defendants' presence during the criminal trial is the most appropriate and the most effective, courts often can't rely solely upon the evidence provided by the prosecution. This fact, according to Macedonian experience, relies to the prosecutors' practice where in many cases supported evidence of the request for imposition of some measure for providing defendant's presence is not sufficient since it lacks important information regarding the defendant's personality of his/hers family or social ties and connections. It is needless to say that this information is of essential importance for the court while deciding whether to impose a measure at all, or to determine the most appropriate measure for providing of the defendants' presence during the trial.

From the comparative point of view, this problem is also observed in other criminal justice systems in EU states. Due to that, several EU member states have introduced within their criminal justice systems specific state agencies which are responsible for gathering and administering these specific evidence to the court regarding the defendants' personality and his/hers social milieu. In most cases these information regarding the defendants' profile to the court as part of the procedure for implementation of the measures for providing of the defendant's presence and as part of the sentencing process are served as the Pre-sentence report by the Police, by the Probation services or by other state bodies.

Delegation of this duty to the Probation services in most cases is justified by the fact that there is strong thread of similarity between the alternative criminal sanctions and the less severe measures for providing of the defendant's presence during the criminal trial, despite the fact that they serve completely different purpose.

In this text author elaborates the jurisdiction of the newly enacted Law on Probation in Republic of North Macedonia and examines the possibility for transferring of this above mentioned duty to the Macedonian probation service in comparison to the jurisdiction of equivalent services in several EU member states. Law on Probation in Republic of North Macedonia was enacted on 25-th of December, 2015 (No. 226/2015) ${ }^{1}$ with vacatio legis until 01-st of November 2016, with main idea to foster and to increase the implementation of the alternative sanctions by

Unfortunately, despite the fact that the vacatio legis has elapsed, this Law has been implemented in practice only since the beginning of 2018, and until now there are only less than 20 Probation officers in the Republic of North Macedonia 
the courts. Unfortunately, this Law has omitted to regulate this additional and equally important area - implementation of the less severe measures than detention for providing of the defendant's presence during the criminal trial. Furthermore, this article also contains specific recommendations for extending of the outreach of the Law on probations.

\section{THEORETICAL BACKGROUND FOR CONNECTION OF THE LESS SEVERE MEASURES FOR PROVIDING DEFENDANT'S PRESENCE AND PROBATION SERVICES}

Considering the nature of the alternative sanctions and the nature and the specific purpose of the less severe measures than detention for providing of the defendant's presence during the trial, it is acceptable to interconnect these two types of measures within one agency for their proper administration. ${ }^{2}$ The interconnection between these two types of measures, as Hucklesby and Marshall ${ }^{3}$ emphasizes lays upon their minimum limitation of the defendant's right to liberty and bears minimum limitation towards their social activities, despite the fact that alternative measures are criminal sanctions and are imposed only upon finished criminal procedure and to the defendants which were found guilty, while the second measures for providing defendants' presence are imposed only to the defendants which are presumed innocent and during the phase of the criminal trial. In addition, these two types of measures identically impose certain obligations or limitations to the defendants in order to test their responsibility and capability to properly function with their everyday life within the community of their origin. ${ }^{4}$

Henceforward the same arguments which are used to justify the necessity to reduce the implementation of the imprisonment sanctions and to foster the imposition of the alternative sanctions are or can be used in the justification of the promotion of the implementation of these less intrusive measures to the defendant's right to liberty in comparison to the detention. ${ }^{5}$

2 See: Gianluka,C., Probation officers are key actors in reforming pre-trial detention and ensuring effective cross-border justice in the EU, available at:[http://cep-probation.org/probation-officers-are-key-actors-in-reforming-pre-trial-detention-and-ensuring-effective-cross-border-justice-in-the-eu/] Accessed 02.04.2019

3 See: Hucklesby A.; Marshall E., Tackling Offending on Bail, The Howard Journal, Vol. 39, No.2. May, 2000, p. 150-170; or for example: Haddad, J. B. et al, Criminal Procedure, Cases and Comments, 5-th ed. Foundation Press, New York, 1998, p. 823-824

4 See: Turnbull S.; Hannah - Moffat, K., Under These Conditions. Gender, Parole and Governance of Reintegration, The British Journal of Criminology, 2009, (1-20), p. 4

5 For the benefits of the imposition of the alternative sanctions see: Kanevcev M., New Alternative Measures in the Macedonian Criminal Code, Macedonian Review for Criminal Law and Criminology, Vol. 13, No. 2, 2006, (191-212), p. 197-200; Buzarovska G., Alternative Measures in Macedonian Criminal 
The reason for this analogy can be found in at least two different aspects.

The first aspect is connected to the empirically proved fact ${ }^{6}$ that the processes of the resocialization and punishment of the convicted persons are far more effective and efficient if this person is not deprived from his/hers natural environment, meaning that the sanction is served within the convicted persons' community. Due to this fact if these arguments are plausible to the convicted persons they should be even more acceptable to the persons whish are standing trial and are protected with the principle of presumption of innocence. Hence, if the defendant is considered innocent until proven guilty it should be also treated likewise by the courts and his/hers right to liberty should be deprived only in specific, limited by law and necessary cases. This means that defendants' presence during the criminal trial in every other case should be provided, if needed, only through the imposition of the less severe measures for providing the defendant's presence. These measures as determined within the Criminal Procedure Code are very similar to the alternative sanctions as regulated within the Criminal Code, particularly regarding their implementation.

Second aspect considers the fact that specific state body or agency is necessary for proper administration of these measures, both the alternative sanctions and the alternatives to detention. Since establishment of a specific state agency for administration of the criminal sanctions is always expensive and connected with significant financial burden to the state's budget, it is also appropriate to provide as much as possible similar workload to these agencies which would reduce the court's or prison authorities' workload, but in the same time it would increase the overall court's and criminal justice system efficiency. This means that if we establish new criminal justice agency, then this agency should be in charged with performance of the complete workload of the other criminal justice stakeholders (such as the courts and prison authorities) that provide same or similar services in order to provide specialization of its services. It is needless to mention that the specialization of the workload of one agency leads to increase of the quality of its work performance. ${ }^{7}$ Additional opinions which support the idea for concentration of the duties for implementation of these measures by the probation services are based upon the facts that probation service officers have more appropriate educa-

Legislation, Macedonian Review for Criminal Law and Criminology, Vol. 13, No. 2, 2006, (213-232), p. 225-227; Gruevska Drakulevski A., The Future of the Imprisonment, Proceedings in Honor of prof. Gjorgji Marjanovik, Faculty of Law, Skopje, 2011, (299-310), p. 305

6 See: Arnaudovski LJ.; Gruevska Drakulevski A., Penology, 2013 Skopje, or Corre N.; Wolchover D., Bail in Criminal Proceedings, 3-rd ed., Oxford University Press, 2007, p. 35

7 See: Kleiman M. When Brute Force Fails, How to Have Less Crime and Less Punishment, Princeton University Press, 2009, p. 184, or Arnaudovski Lj., Court Management, Skopje, 2010 
tional background and experience than the police officers for implementation of these measures. This, on the other hand, generates better interpersonal relations between the parole officers and the defendants, which means better answer to the defendant's needs and overall improves the satisfaction from the implementation of these measures during the trial by the defendants ${ }^{8}$. In this sense it could be expected that the defendants would be more willing to obey the court's imposed orders and reduce the possibility of risk of absconding or possible further committing crimes as defendants' desired and expected behavior.

Hence more, considering the EU member states' criminal justice systems, together with the EU acquis, we can conclude that this jurisdiction of the Probation services is often common in most states that do have established such specific service. For example this experience of the Probation service can be found within the criminal justice systems in several EU member states, such as Netherlands, Belgium, Slovakia, UK or Austria. ${ }^{9}$ Furthermore, in most of the EU member states Probation services are providing presentence reports or are performing personal information data gathering for the courts which provides the necessary information of the defendant's character and social ties to the judges while determining which is the most appropriate measure for providing of the defendant's presence during the criminal trials. ${ }^{10}$

Possibility of interconnection of the implementation of the alternative sanctions and less severe measures than detention can be also indirectly concluded trough the EU acquis ${ }^{11}$. The most important document on EU level regarding the implementation of the measures for providing of the defendants' presence is EU's Framework Decision 2009/829/JHA ${ }^{12}$ on supervision measures as an alternative to provisional detention. Hence, in the article 6 of this Framework Decision it is regulated that the jurisdiction for implementation of the alternatives to detention rests upon state agencies, while omitting direct specification of which specific state

8 See: Porporino, F., Developments and challenges in probation practice: Is there a way forward for establishing effective and sustainable probation systems?, European Journal of Probation, Vol. 10(1) 76- 95, 2018; or: Nagy, S., Use and Abuse of Pre-Trial Detention in Council of Europe States: A Path to Reform, 13 Loy. U.Chi. Int'l L. Rev. pp. 159, 2016

$9 \quad$ For extensive information see: Kalmthout, A.M.; Durnescu, I. (eds.). Probation in Europe, Wolf Legal Publishers, 2009

10 Ibid.

11 Since Republic of North Macedonia is a candidate member state to the EU, and has started its accession process through its specific "High Level Accession Dialogue - HLAD" process, it is needless to mention that EU acquis is also source of law for our national legal system and Macedonian legal system need to be harmonized with the EU acquis

12 EU Framework decisions No. 2009/829/JHA on supervision measures as an alternative to provisional detention 
agency is responsible for this. Due to this fact we can conclude that there is no formal objection for Probation agencies to implement these less severe measures to detention.

In regard to the above mentioned arguments we can conclude that despite the fact that on first sight it might appear that we are comparing "apples and pears", these two types of measures are having significant mutual resemblance. This is primarily based upon the facts that the implementation of these less severe measures and the alternative sanctions in practice is usually connected with same or similar problems and they have similar implementation methodology.

Due to this, in the next chapter we will critically examine the provisions of the Macedonian Law on Probation and trough the comparative method we will examine the areas where this law could be improved in order to be suitable tool for proper implementation of the less severe measures than detention by the Macedonian courts.

\section{ANALYSIS OF THE JURISDICTION OF THE MACEDONIAN LAW ON PROBATION}

The enactment of the Law on Probation ${ }^{13}$ was eagerly expected by the Macedonian academics and judicial professionals since it was considered as one useful and necessary tool for proper implementation of the alternative measures together with the improved implementation of the less severe measures than detention during the criminal trials. Unfortunately, it is obvious that the Macedonian legislator has significantly reduced the impact of this law only within the implementation of the alternative measures to prison as regulated within the Criminal Code ${ }^{14}$ and somehow has timidly introduced risk evaluation as possibility for assistance to the judges.

Having on mind several EU member states' experience, ${ }^{15}$ together with the experience of the US Probation Services, it is obvious that Macedonian Law on Probation does not regulate the area of the support for the implementation of measures for providing of the defendants' presence. This situation is rather unusual, since it is not clear why this significant and eminent jurisdiction of the probation

\footnotetext{
13 See articles 1 and 3 of the Law on Probation, Official Gazette of Republic of Macedonia, No. 226/2015

14 Criminal Code, Official Gazette of Republic of Macedonia, No. 37/1996 with the latest amendments of 21.12.2018.

15 For Austrian experience see: [http://cep-probation.org/wp-content/uploads/2015/03/Probation-in-Europe-2013-Chapter-Austria.pdf] or for Italian experience: [http://cep-probation.org/wp-content/uploads/2016/04/Chapter-Italy-final.pdf] Accessed 02.04.2019
} 
services ${ }^{16}$ was omitted from the Macedonian legislator. Furthermore, besides the implementation of the alternative sanctions, and measures for providing of the defendant's presence, another most common official duty of the probation services ${ }^{17}$ are support to the courts while implementation of the less severe measures than detention for providing of the defendants presence and providing risk evaluation of the defendants' personal character. ${ }^{18}$

In order to exam whether there are actual possibilities for extension of the jurisdiction of the Macedonian probation service we need to evaluate the actual reach of the provisions of the Law on Probation, together with the correlation between the alternative sanctions and the measures for providing of the defendants' presence. Finally, we need to evaluate the correlation to the EU standards and whether they are in correlation to the types of alternative sanctions which are dealt by the Macedonian probation services.

\subsection{Probation services during the criminal procedure and implementation of the risk evaluation schemes}

In most of the criminal justice systems where the probation service is established, one of its core duties is the analysis of the defendants' personality, trough creation of the risk evaluation schemes ${ }^{19}$. Performance of the risk evaluation is particularly important for the courts while deliberating the most appropriate measure for providing defendant's presence during the criminal trial, or sanction at the end of the criminal trials. ${ }^{20}$

16 For the jurisdiction and organization of US Probation and Pretrial Services System see: [http://www. uscourts.gov/services-forms/probation-and-pretrial-services] Accessed 02.04.2019, or Haddad, J. B., et al, Criminal Procedure, Cases and Comments, 5-th ed. Foundation Press, New York, 1998

17 Pretrial Service and the Probation service are part of the Administrative Office of the US Federal Courts. Despite the fact that these two distinct services are particularly administering the part of the criminal justice process where they are involved, in fact they are part of one state agency. See: [http:// www.uscourts.gov/services-forms/probation-and-pretrial-services/probation-and-pretrial-services-history] Accessed 02.04.2019

18 See: Abadinsky H., Probation and Parole, Theory and Practice, 7-th Ed., Prentice Hall, 2001, p. 3

19 See: A Measure of Last Resort? The practice of pre-trial detention decision making in the EU, Fair Trials, available at: [https://www.fairtrials.org/wp-content/uploads/A-Measure-of-Last-Resort-Full-Version.pdf] Accessed 02.04.2019 or: Persson A.; Svensson, K., Shades of Professionalism: Risk Assessment in Pre-Sentence Reports in Sweden, European Journal of Criminology, Vol. 9 (2), 2012; or: Ostrom, B.J.; Kauder, N.B., The Evolution of Offender Risk Assessment in Virginia, Federal Sentencing Reporter, Vol. 25, N0. 3,2013, pp. 161-167, Retrieved from: Vera Institute of Justice.

20 See: Tombs J.; Jagger, E., Denying Responsibility, Sentencers' Accounts of their Decisions to Imprison, British Journal of Criminology, 2006, (803-821), \. 810; or: Rumgay J. Custodial Decision Making in a Magistrate Court, Court Culture and Immediate Situational Factors, The British Journal of Criminology, Vol. 35, No.2, 1995, (201-217), p. 214 
Fortunately, this duty of the probation service has been envisioned by the Macedonian legislator and within the Article 12 of the Macedonian Law on Probation. This article regulates the obligation of the probation services to summon the defendant and to perform an interview with him/her, and/or to collect additional documents and personal data from other state agencies as requested by the courts and by using specific risk assessment tools to generate final report to the court regarding the defendants' state of risk.

However, despite the fact that duty of the Macedonian probation service means great improvement of the judges' position, unfortunately the authorization for the judge to request this information from the probation service has not yet been prescribed within the provisions of the Criminal Procedure Code ${ }^{21}$. This means that, at this point, there are no legal grounds within the Criminal Procedure Code for the judges to undertake the activities as regulated within the article 12 of the Macedonian Law on Probation.

Therefore we think that this legal situation should be implemented within the new amendments of the Criminal Procedure Code ${ }^{22}$ in order to introduce the possibility for the court to request from the probation service performance of the risk evaluation schemes and presentence reports as part of the courts' decision making process for implementation of the measures for providing of the defendant's presence or of the alternative sentences. Hence we think that only with this provisions in the CPC, the judges will be able to use this probation services' duty as an effective tool for assessment of the most suitable measure for providing defendant's presence.

\subsection{Similarities between the less severe measures than detention for providing defendant's presence during the criminal trials and alternative sanctions}

As a precondition to the determination whether it is possible to transfer the authority of implementation of the less severe measures for providing of the defendant's presence during criminal trial to the probation services it is necessary to analyze the level of similarity between these measures and the alternative sanctions. The level of similarity between these measures rests upon the fact that implementa-

21 Criminal Procedure Code, Official Gazette of Republic of Macedonia, No. 150/2012

22 Macedonian Ministry of Justice has formed a work group for drafting of the amendments and changes to the Macedonian Criminal Procedure Code. However, the Draft-Amendments have been officially published only on the Ministry of Justice's web page as part of the public debate process, but these amendments are not entered into Parliamentary procedure for enactment until 15.3.2019. Unfortunately, these amendments do not contain any amendments regarding the presentence reports or risk evaluation for the defendants 
tion of alternative sanctions and the alternatives to detention bear same or similar burden regarding the professionalism and knowledge of the probation agencies' employees. Hence, it is often practical to correlate implementation of these two types of measures into one state agency.

Macedonian legislator within the article 144 of the Criminal Procedure Code has regulated the following measures for precaution: ban for leaving the residence, mandatory reporting to a specific state organ or official person, temporary ban of driving license or ban for its issue, temporary ban of the passport or ban for its issue, temporary restriction for visiting specific places or areas, restrictions regarding maintaining contact with specific persons and temporary ban for undertaking specific professional activities or work related activities. These measures together with the house detention, bail, short time detention and citation as considered as less severe measures to detention and serve for providing of the defendants presence during the criminal trials. The above mentioned measures for providing of the defendants' presence during the criminal trials are also harmonized with the EU Framework Decision 2009/829/JHA on Supervision Measures as an Alternative to Provisional Detention. ${ }^{23}$ The general idea for implementation of these measures is based upon the theory that the defendant's right to liberty will be of primal importance, while this right might be limited only in inevitable cases, where the detention, as most severe measure, will be imposed only in strictly limited and necessary cases.

Considering the effect and implementation of these measures, it is obvious that they carry resemblance with several of the alternative sanctions as defined within the Criminal Code. It is also useful to mention that alternative sanctions which are regulated within the Criminal Code are also harmonized with the EU Framework Decision 2008/947/JHA on Probation Decisions and Alternative Sanctions and Framework Decision 2008/909/JHA on the Mutual recognition of Judicial Decisions on Custodial Sentences or Measures Involving Deprivation of Liberty. ${ }^{24}$ Furthermore both of these measures are following Council of Europe's Recommendations regarding the deprivation of liberty and alternative sanctions. ${ }^{25}$ In the

23 See EU Framework Decision No. 2009/829/JHA on supervision measures as an alternative to provisional detention

24 See: EU Framework decisions No.: 2008/909/JHA on the mutual recognition of judicial decisions on custodial sentences or measures involving deprivation of liberty; and 2008/947/JHA on probation decisions and alternative sanctions

25 See: Council of Europe's Recommendations: Rec(2006)13 of the Committee of Ministers to member states on the use of remand in custody, the conditions in which it takes place and the provision of safeguards against abuse, available at: https://search.coe.int/cm/Pages/result_details.aspx?Objec$\mathrm{tID}=09000016805 \mathrm{~d} 743 \mathrm{f}$, and $\operatorname{Rec}(2010) 1$ of the Committee of Ministers to member states on the 
later lines we will demonstrate the exact similarities between the above mentioned types of measures.

3.2.1. At the beginning, it is obvious that the most similar measures are house detention as regulated with the article 163 of the Criminal Procedure Code and house imprisonment as regulated with article 58-a of the Criminal Code. Despite the fact the Macedonian legislator has opened the legal lacunae for implementation of the house detention, ${ }^{26}$ contrary to the nature of this measure, to every defendant and not only limiting it to pregnant women, chronically diseased and elder people, as defined with the house imprisonment within the provisions of the Criminal Code.

These two measures bear significant resemblance due to the fact that both of them are implemented within the premises of the defendant's or convict's house, together with the fact that control over the implementation of this measure, so far, has been performed by the police officers. This means that with both measures the convicted person or the detainee should not leave the premises of the house or residence, while supervision and control of the proper implementation, so far until the enactment of the Law on Probation, was dedicated to the police officers. Granting the implementation of the house imprisonment to the probation service is far more efficient and effective, since the probation service's officers have additional knowledge and training than regular police officers, in order to be able to determine whether the detainees or convicted persons are law abiding citizens and that they do obey the limitations and restrictions imposed by the court with these measures. In addition, police officers, generally, are not sufficiently trained regarding meeting these specific duties, which in this situation leaves them unguarded or unprepared, regarding the possible obstructions or factual needs of the detainees or convicted persons, which means that they can't provide the proper support or monitoring over the less severe measures for providing defendants' presence.

3.2.2. Similar arguments can be set regarding the implementation of the electronic monitoring, ${ }^{27}$ which is defined as a measure for support of the implementation of the house detention within the provisions of the article 163 of the CPC. ${ }^{28}$ Unfortunately this measure is also not covered by the provisions of the

Council of Europe Probation Rules, available at: [https://search.coe.int/cm/Pages/result_details.aspx?ObjectID=09000016805cfbc7] Accessed 02.04.2019

26 See: Misoski B., Bail, precaution measures andlor house detention: analysis and recommendations for their more frequent use, Proceedings of the Post Doc Colloquium in Public Law, Tirana and Skopje, SEELS Network, 2014

27 See Article 25 of the Law on Probation

28 See Article 163 of the CPC, Official Gazette, No. 150/2010 
Law on Probations, despite the fact that the probation service is the most suitable state agency for undertaking these activities. In addition, implementation of the electronic monitoring within the $\mathrm{CPC}$ remains vaguely regulated, since the $\mathrm{CPC}$ is does not provide further provisions regarding this issue and probably it should be regulated with additional legal bylaws or other laws. ${ }^{29}$

3.1.3. The same dilemma can be raised regarding the implementation of the precaution measures as regulated within the CPC. ${ }^{30}$ Hence, it remains the fact that there is strong treat of similarity between the measures of the article 144 of the CPC: ban of leaving the premises of the house or residence, obligation for report to the specific official body, ban of visit specific premises or areas, ban of contacting with specific persons, ban related undertaking specific work related activities; and measures regulated within the article 58, paragraphs 1, 6, 7 and 9 of the Criminal Code which are regulating the control over the additional obligations determined together with the conditional sentence with protective supervision. Considering the provisions of this article of the Criminal Code we can conclude that the Criminal Code has regulated the very same measures as support to defendant's conditional sentence. The only obvious difference is that the first measures are imposed prior to the sanction and are implemented to presumed innocent person during the criminal trial, while the second measures are considered as sanctions imposed to guilty persons as determined by the court after the criminal trial.

3.2.4. Hence, even grater similarity is obvious between the measures ban for issuance of the driving license or temporary cease of the driving license, article 144 of CPC, and the sentence ban for driving of motor vehicle as regulated within the article 38-c of the Criminal Code. Meaning that despite the fact that the one is criminal sanction, while the former is measure for providing the defendant's presence, both measures are bearing the same effect - ban of operating motor vehicle.

3.2.5. The same can be said regarding the sanction ban of performing specific work related activities as regulated within article 38-b of the Criminal Code and the measure for temporary ban of performing specific work related activities

\footnotetext{
29 See: paragraph 4 and 5 of the Article 163 of the CPC

30 For instance the Legal Analysis as supportive document to the Strategy does not contain any information regarding the reasons for not implementing the less severe measures than detention for providing of the defendants' presence during the criminal trials as part of the Law on Probation, only mentioning the house detention. Hence, it is not clear whether the authors of the Strategy have evaluated the possibility for implementation of these less severe measures to detention as part of the Law on Probation at all
} 
as regulated in the article 144 of the CPC. Furthermore, these both measures (as discussed in 3.2.4 and in this paragraph) at the moment are implemented by the police, or court and, unfortunately, are not transferred under the jurisdiction of the Probation Services.

This simple "face-to-face" comparison between these alternative sanctions and the preventive measures for providing the defendant's presence during the criminal trial reveals the pattern that, despite the fact that between the two measures are significant differences regarding the purpose of their implementation, the practical implementation is the same.

However, leaving these measures to be implemented by two, or sometimes three different state agencies, one to the probation service supported with additional training regarding meeting the convicted persons' personal needs and characteristics, while the second implemented by the police and courts that does not have any understandings regarding the defendants' personal needs and characteristic, opens the floor for unequal and erroneous implementation.

Due to these facts, we deem that the implementation of the preventive measures as regulated within the $\mathrm{CPC}$ should be delegated to the probation service, since this service, if properly staffed with trained employees, should implement these measures with greater success, particularly taking into consideration the needs and individual characteristics of the defendants' and not disregarding the aim of the criminal justice process. ${ }^{31}$

Furthermore, testing of one similar measure during the criminal trial could provide significant insight to the law-enforcement agencies regarding the effectiveness of this measure to the specific persons if it will be imposed at the end of the criminal trial as a sanction. This means that the effectiveness of one measure imposed to the defendant regarding his/hers preparedness to follow instructions, obeying certain rules etc., can be evaluated during the early stages of the criminal procedure.

On the other hand imposition of these measures automatically as a sanction, simply because they were implemented as a measure during the criminal trial, without knowing the insight of the real defendant's behavior during the imposition of this measure within the criminal trial, is also not acceptable or desirable practice. Due to the fact that the defendant has different motivations during the criminal trial,

31 For example see the USA Probation services' or UK Probation services' experience: Hucklesby A., Bail Support schemes for Adults, The Policy Press, University of Bristol, UK, 2011, p. 18, and Dhami Mandeep K., Do Bail Information Schemes Really Affect Bail Decisions?, The Howard Journal, Vol. 41, No. 3, 2002, (245-262), p. 248-250 
where he/she is presumed innocent and at the end of the trial where he/she is proven to be guilty.

This practice is comprehensively elaborated by the case law of the European Court of Human Right in several judgments where the court is elaborating the reasoning of the implementation of these measures during the trial and at the end of the trial as sanctions. ${ }^{32}$

Finally, by establishing of the implementation of these two types of measures "under the hood" of one state agency will increase the imposition and implementation these measures and sanctions, since the judges will be confident that there is one state agency which undertakes all necessary preconditions for proper implementation of these measures. Furthermore, in correlation to the risk evaluation schemes judges would be completely certain that they have done the right selection and made a proper decision regarding the special and general prevention, as general aim of the criminal justice process. ${ }^{33}$

\section{CONCLUSION}

The enactment of the new Law on Probation in Republic of North Macedonia has been long expected as an effective tool for judges for implementation of the alternative sanctions and less severe measures for providing defendant's presence as an alternative to detention.

Unfortunately, Macedonian Law on Probation has failed to meet these expectations. This is due to the fact the Macedonian legislator with the enactment of the Law on Probation has omitted to regulate the implementation of the alternative measures to detention as a measures for providing of the defendant's presence during the criminal trials, despite the fact that this part of the criminal justice system can be considered as genuine area of jurisdiction of the probation services. This is based upon the fact that there is great resemblance between the implementation and the essence of the alternative sanctions and the measures for providing of the defendant's presence which are less severe than detention during the trial. This resemblance is noted both trough comparative criminal law perspective, but

32 See ECtHR's judgement: Wemhoff v. Germany, available at: [http//hudoc.echr.coe.int/sites/eng/pages/search.aspx?i=001-57595] Accessed 02.04.2019

33 See: Buzarovska G.; Andreevska S.; Tumanovski A., Application of the Pretrial Detention Pursuant to the Criminal Procedure Code of 2010 - Legal Analysis, OSCE, Skopje, 2015; Misoski B., Protection of the Right to Bail as a Derived Human Right from The Article 5 of the ECHR in Macedonia, SEE-LAW NET: Networking of Lawyers in Advanced Teaching and Research of EU Law post-Lisbon Outcome of the SEE Graduates EU Law Teaching \& Research Academy Collection of Papers, Saarbrucken, Germany 2013 
also considering the positive regulation within the Macedonian criminal justice system.

Having on mind the comparative experience from several EU member states we can conclude that probation services are usually preferable choice than police for implementation of these less severe measures for providing defendant's presence. This is due to the fact that probation services are, generally, more specialized, better trained and staffed and better equipped for undertaking these activities than police or other state agencies.

Finally, in order to improve the practical implementation and increase the frequency of these less severe measures than detention it is necessary to introduce legal amendments of the Law on Probation which will allow Macedonian probation service jurisdiction over the implementation of these measures. Amendments should be also performed to the Criminal Procedure Code, where this duty of implementation of these less severe measures for providing defendant's presence will be delegated to the Probation Services.

\section{REFERENCES}

\section{BOOKS AND ARTICLES}

1. Abadinsky, H., Probation and Parole, Theory and Practice, 7-th Ed., Prentice Hall., 2001

2. Arnaudovski, Lj. and Gruevska Drakulevski, A., Penology, 2-ri Avgust, Stip, 2013

3. Arnaudovski, Lj., Court Management, 2-ri Avgust Stip, 2010

4. Buzarovska, G., Alternative Measures in Macedonian Criminal Legislation, Macedonian Review for Criminal Law and Criminology, Vol. 13, No. 2., 2006, p. 213-232

5. Buzarovska, G.; Andreevska, S.; Tumanovski, A., Application of the Pretrial Detention Pursuant to the Criminal Procedure Code of 2010 - Legal Analysis, OSCE, Skopje, 2015

6. Corre, N. and Wolchover, D., Bail in Criminal Proceedings, 3-rd ed., Oxford University Press, 2007

7. Dhami, M.K., Do Bail Information Schemes Really Affect Bail Decisions?'The Howard Journal, Vol. 41, No. 3, 2002, p. 245-262

8. Gruevska Drakulevski, A., The Future of the Imprisonment, Proceedings in Honor of prof. Gjorgji Marjanovik, Faculty of Law, Skopje, 2011, p. 299-310

9. Haddad, J.B. et al, Criminal Procedure, Cases and Comments, 5-th ed. Foundation Press, New York, 1998

10. Hucklesby, A., Bail Support Schemes for Adults, The Policy Press, University of Bristol, UK, 2011

11. Hucklesby, A.; Marshall, E., Tackling Offending on Bail, The Howard Journal, Vol. 39, No.2, 2000, p. $150-170$

12. Kambovski, V., Criminal Law - substantive part, Kultura, Skopje, 2004 
13. Kanevcev, M., New Alternative Measures in the Macedonian Criminal Code, Macedonian Review for Criminal Law and Criminology, Vol. 13, No. 2, 2006, p. 191-212

14. Kleiman, M., When Brute Force Fails, How to Have Less Crime and Less Punishment, Princeton University Press, 2009

15. Misoski, B., Protection of the Right to Bail as a Derived Human Right from The Article 5 of the ECHR in Macedonia, SEE-LAW NET: Networking of Lawyers in Advanced Teaching and Research of EU Law post-Lisbon Outcome of the SEE Graduates EU Law Teaching \& Research Academy Collection of Papers, Saarbrucken, Germany, 2013

16. Misoski, B., Bail, precaution measures and/or house detention: analysis and recommendations for their more frequent use, Proceedings of the Post Doc Colloquium in Public Law, Tirana and Skopje, SEELS Network, 2014

17. Nagy, S., Use and Abuse of Pre-Trial Detention in Council of Europe States: A Path to Reform, 13 Loy. U. Chi. Int'l L. Rev, 2016

18. Ostrom, B.J.; Kauder, N.B., The Evolution of Offender Risk Assessment in Virginia, Federal Sentencing Reporter, Vol. 25, N0. 3, 2013, pp. 161-167

19. Persson, A.; Svensson, K., Shades of Professionalism: Risk Assessment in Pre-Sentence Reports in Sweden, European Journal of Criminology, Vol. 9 (2), 2012

20. Porporino, F.J., Developments and challenges in probation practice: Is there a way forward for establishing effective and sustainable probation systems? European Journal of Probation, Vol. 10 (1), 2018

21. Rumgay, J., Custodial Decision Making in a Magistrate Court, Court Culture and Immediate Situational Factors, The British Journal of Criminology, Vol. 35, No.2, 1995, pp. 201-217

22. Tombs, J.; Jagger, E., Denying Responsibility, Sentencers' Accounts of their Decisions to Imprison, British Journal of Criminology, 2006, pp. 803-821

23. Turnbull, S.; Hannah - Moffat, K., Under These Conditions. Gender, Parole and Governance of Reintegration, The British Journal of Criminology, 2009, p. 1-20

\section{EU LAW}

1. EU Framework decision No.: 2008/909/JHA on the mutual recognition of judicial decisions on custodial sentences or measures involving deprivation of liberty

2. EU Framework Decision No. 2008/947/JHA on probation decisions and alternative sanctions

3. EU Framework Decision No. and 2009/829/JHA on supervision measures as an alternative to provisional detention

\section{NATIONAL REGULATIONS, ACTS AND COURT DECISIONS}

1. Criminal Procedure Code, Official Gazette, No. 150/2010

2. Criminal Code, Official Gazette of Republic of Macedonia No. 19/2004

3. Law on Probation, Official Gazette, No. 226/2015

4. Strategy for Development of the Probation Service in Republic of Macedonia, (2013-2016). Retrieved at: [www.pravda.gov.mk/UIS/1_strategija.doc] Accessed 10.03.2019 
5. Legal Analysis for Changes and Amendments of the Legislative Framework in Republic of Macedonia, regarding the development of the Probation Service. Retrieved at: [http://www. pravda.gov.mk/tekstoviuis.asp?lang=mak\&id=uisstrat] Accessed 10.03.2019

\section{WEBSITE REFERENCES}

1. A Measure of Last Resort? The practice of pre-trial detention decision making in the EU, Fair Trials, retrieved at: [https://www.fairtrials.org/wp-content/uploads/A-Measure-of-LastResort-Full-Version.pdf] Accessed 10.03.2019

2. Austrian Law on Probation, Retrieved at: [http://cep-probation.org/wp-content/uploads/2015/03/Probation-in-Europe-2013-Chapter-Austria.pdf] Accessed 10.03.2019

3. $\mathrm{CM} / \operatorname{Rec}(2010) 1$ of the Committee of Ministers to member states on the Council of Europe Probation Rules, Retrieved at: [https://search.coe.int/cm/Pages/result_details. aspx?ObjectID=09000016805cfbc7] Accessed 10.03.2019

4. Council of Europe's Recommendation: Rec(2006)13 of the Committee of Ministers to member states on the use of remand in custody, the conditions in which it takes place and the provision of safeguards against abuse, Retrieved at: [https://search.coe.int/cm/Pages/result_details.aspx?ObjectID=09000016805d743f] Accessed 10.03.2019

5. Gianluka, C., Probation officers are key actors in reforming pre-trial detention and ensuring effective cross-border justice in the EU, 2017. Retrieved at: [http://cep-probation.org/ probation-officers-are-key-actors-in-reforming-pre-trial-detention-and-ensuring-effectivecross-border-justice-in-the-eu/] Accessed 10.03.2019

6. Italian Law on Probation, Retrieved at: [http://cep-probation.org/wp-content/uploads/2016/04/Chapter-Italy-final.pdf] Accessed 10.03.2019

7. Macedonian Statistical Bureau. Data Retrieved at: [http://www.stat.gov.mk/PrikaziSoopstenie.aspx?rbrtxt=14] Accessed 10.03.2019

8. US Probation and Pretrial Services System, Retrieved at: [http://www.uscourts.gov/servicesforms/probation-and-pretrial-services] Accessed 10.03.2019

9. Wemhoff v. Germany, Retrieved at: [http//hudoc.echr.coe.int/sites/eng/pages/search. aspx?i=001-57595] Accessed 10.03.2019 